\title{
THE EFFECT OF PHASE NUTRITION DURING STARTER PERIOD ON PRODUCTION PERFORMANCES AND NITROGEN CONTENT IN FECES OF BROILERS OF DIFFERENT GENOTYPES
}

\author{
N. Tolimir ${ }^{1}$, L. Perić ${ }^{2}$ N. Milošević ${ }^{2}$ M. Đukić - Stojčić ${ }^{2}$ R. Jovanović ${ }^{1}$, \\ V. Bogdanovic ${ }^{3}$
}

\author{
${ }^{1}$ Institute of Science Application in Agriculture' Bulevar Despota Stefana 68b, 11000, Belgrade, \\ Republic of Serbia \\ ${ }^{2}$ Faculty of agriculture, University of Novi Sad, Trg Dositeja Obradovića 8, 21000, Novi Sad, \\ Republic of Serbia \\ ${ }^{3}$ Faculty of Agriculture, University of Belgrade, Nemanjina 6, 11080 Belgrade, Republic of Serbia \\ Corresponding author: e-mail: ntolimir@ipn.co.rs \\ Original scientific paper
}

\begin{abstract}
Objective of the research was to investigate the effect of phase nutrition, i.e. different mixtures used in broiler nutrition with phase reduction of protein cotnent during starter period on production peformances of fattening chickens of diferent genotypes and on nitrogen content in faeces. Differences between groups (treatments) were in the type of mixtures use din starter period, and according to the following program: T1 (control group) - nutrition consisted of mixtures with $23 \%$ of proteins in duration from day 1 to 21 ; T2 - from day 1 to 14 , mixture containing $23 \%$ of protein was used, and from day 14 to 21 , mixture with $20 \%$ of proteins; T3 - from day 1 to 7 , mixture was used containing $23 \%$ of protein and from day 7 to 21 , mixture with $20 \%$ of proteins; T4 - nutrition with mixture containing $20 \%$ of proteins in duration from day 1 to 21 . During the trial period (from day 1 to 21 ) production parameters were followed. Nitrogen content was determined in a collective faeces sample. Results showed that chickens of different genotypes expressed different sensitivity to protein restriction. Comparing the trial groups with the control in the third week, in chickens of Ross 308 provenience significantly lower body weight was registered only in chickens of T4 group with the highest protein reduction. In Cobb 500 chickens, significantly lower body weight was determined in T3 and T4 trial groups. In case of both hybrids, in T2 group, slightly lower body weight was established, but without statistically significant difference compared to the control. Feed conversion in both genotypes was the highest in T3 and T4 treatments. The program of phase nutrition resulted in decrease of the nitrogen content in faeces. Based on obtained data it can be concluded that applied nutrition treatments with drastic protein reduction during starter period in both genotypes had negative effect on production performances.
\end{abstract}


Therefore, the composition and dynamics of mixture changes must be taken into consideration when formulating the program of phase nutrition, in order to achieve both goals - decrease of protein content in feed with simultaneous diminished nitrogen excretion and achieving good results.

Key words: broiler, genotype, phase nutrition, production traits, nitrogen

\section{Introduction}

In regard to broiler fattening periods, the early period is given special attention, and nutrition during the starter period is considered critical for realization of optimum production performances, therefore is the topic of research by numerous authors (Baker and Han, 1994; Gomes et al., 2006). Studies show that the protein and amino acid requirements of broilers change with their age, also that the use of one diet during longer period of time would result either in nutrient suficit or deficit during most of the growth period. In this regard, Belyavin, (1999) suggests that during the growing period more different diets are used, i.e. that nutrition of broilers is based on programs of multiphase nutrition. Studies show that mixtures with reduced protein content have no effect on body weight and feed intake of broilers, i.e. their impact on economical efficiency of broiler fattening is significant (Warren and Emmert, 2000; Saleh et al., 1996). Numerous programs of phase nutrition have been developed in the last decade which are based on different frequencies of changes of certain mixtures, i.e. starter, grower and finisher in broiler nutrition. Main objective of phase nutrition programs is to determine the optimum time proportion in nutrition using basic mixtures, in regard to production performances and economical efficiency of production, but often also the ecological aspect of these programs is considered (Roush et al., 2004; Saleh et al., 2004). Also, it can be observed that programs include certain combinations of minimum three to twenty mixtures of different nutritional composition (Buteri et al., 2009; Tolimir et al., 2010), with aim to determine the optimal program. Economical impact of substitution starter with grower mixture in early period is based on the difference in cost of starter and finisher diets. In addition to the economical impact of the phase nutrition program, the studies include also the ecological aspect, considering that it was established that nitrogen excretion is directly correlated to protein content in mixtures used in nutrition (Bregendahl et al., 2002). However, study results (Ferguson et al., 1997) indicate that drastic reduction of crude proteins during the first three weeks can significantly increase the need for feed in broilers, therefore it is not recommended, although reduction of crude proteins resulted in decrease of nitrogen emission. The same author (Ferguson et al., 1998) points out that feed manipulation can have impact on 
reduction of nitrogen in manure, but at the same time production performances are maintained at the acceptable level.

Objective of the present paper is to investigate the effect of the nutrition program which includes several phases, i.e. the effect of different mixtures used in broiler nutrition, where protein content is reeduced in phases - in the first fattening phase, on production traits of fattening chickens of different genotypes and nitrogen content in faeces.

\section{Material and Methods}

Trial was carried out on Experimental farm of the Faculty of Agriculture, Novi Sad in Temerin. The study included 1200 individually marked chickens of Ross 308 and Cobb 500 proveniences. Chickens were housed in 16 boxes, 75 chickens in each box. Within each genotype, four groups - treatments were formed, with two repetitions for each treatment. For every treatment 150 chickens per treatment were studied.

Standard fattening technology was applied, in duration of 42 days. Chicken nutrition was ad libitum. Difference between groups (treatments) was in the type of mixture used in starter period, and according to the following program of phase nutrition: T1 (control group) - nutrition consisted of mixtures with $23 \%$ of proteins in duration from day 1 to 21 ; T2 - from day 1 to 14 , mixture containing $23 \%$ of protein was used, and from day 14 to 21 , mixture with $20 \%$ of proteins; T3 - from day 1 to 7 , mixture was used containing $23 \%$ of protein and from day 7 to 21 , mixture with $20 \%$ of proteins; T4 - nutrition with mixture containing $20 \%$ of proteins in duration from day 1 to 21 .

Control measuring of all individually marked chickens was done using technical scale on the first day and in weekly intervals from week 1 to 3 . Feed conversion was calculated based on data on feed intake and gain of chickens at the level of every chicken box, and all dead chickens were also weighed and included in the calculation.

Chemical analysis was carried out on the collective faeces sample, as well as determination of nitrogen content. Collective faeces sample was formed by collecting faeces from trial boxes for studied treatments. Faeces were collected using a wooden box with wire basis on which a nylon layer was placed, and where chickens were kept for certain period of time necessary for taking of samples. Nitrogen content in faeces was analyzed in the Laboratory for quality of animal feed of the Faculty of Agriculture in Novi Sad, according to the method 7 of the Rulebook on methods for taking of samples and methods of physical, chemical and microbiological analysis of animal feed (1987).

The program STATISTIKA, ANOVA MANOVA and LSD post-hoc test were used in data processing. 


\section{Results and Discussion}

Based on obtained data, it was established that applied program of phase nutrition during starter period, in both investigated proveniences, resulted in expression of impact on production performances, i.e. body weight and feed conversion.

In Table 1, the weekly evaluation of the significance of differences of major factors on body weight of Cobb 500 and Ross 308 chickens is presented. Hybrid was determined to be significant only in the first week, which can be associated with the research by Petričevič et al. (2011), whereas the feed as variability factor had statistically significant effect on body weight in all trial weeks. Interaction between factors hybrid and feed was not recorded in the third week.

By observing the data obtained in different nutrition treatments, it is apparent that hybrids reacted differently on applied nutrition programs. In case of provenience Cobb 500 significant difference between the control - T1 compared to chickens of group T3 which consumed starter mixture only in the first 7 days and T4 group which did not consume starter diet during first three weeks, was established. In Ross 308 chickens, statistically significant difference was determined only between $\mathrm{T} 1$ and $\mathrm{T} 4$ groups, which can indicate that chickens of this provenience were more tolerant to shortening of the nutrition with starter mixture.

Table 1. Evaluation of significane of differences in body weight, per weeks

\begin{tabular}{|c|c|c|c|c|c|c|c|c|c|c|c|c|}
\hline \multirow{3}{*}{$\begin{array}{l}\frac{y}{8} \\
3 \\
3\end{array}$} & \multirow{3}{*}{ 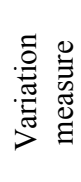 } & \multicolumn{11}{|c|}{ Average body weight (g) } \\
\hline & & \multicolumn{4}{|c|}{ Cobb 500} & \multicolumn{4}{|c|}{ Ross 308} & \multicolumn{3}{|c|}{ Factor } \\
\hline & & T1 & $\mathrm{T} 2$ & $\mathrm{~T} 3$ & $\mathrm{~T} 4$ & T1 & $\mathrm{T} 2$ & $\mathrm{~T} 3$ & $\mathrm{~T} 4$ & 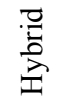 & $\begin{array}{l}\text { D } \\
\mathbb{0} \\
\text { L }\end{array}$ & $\stackrel{\text { L }}{\underline{x}}$ \\
\hline \multirow{2}{*}{1.} & $\bar{x}$ & $144^{\mathrm{a}}$ & $147^{\mathrm{a}}$ & $143^{\mathrm{a}}$ & $118^{\mathrm{b}}$ & $159^{\mathrm{a}}$ & $161^{\mathrm{a}}$ & $156^{\mathrm{a}}$ & $126^{b}$ & $* *$ & ** & * \\
\hline & $\mathrm{Sd}$ & 18,47 & 17,18 & 19,76 & 11,25 & 17,92 & 18,84 & 19,29 & 16,04 & & & \\
\hline \multirow{2}{*}{2.} & $\bar{x}$ & $333^{\mathrm{a}}$ & $333^{\mathrm{a}}$ & $315^{b}$ & $262^{\mathrm{c}}$ & $336^{\mathrm{a}}$ & $346^{\mathrm{a}}$ & $315^{b}$ & $283^{\mathrm{c}}$ & NS & ** & ** \\
\hline & $\mathrm{Sd}$ & 58,82 & 42,07 & 40,98 & 38,99 & 51,71 & 54,05 & 52,07 & 43,09 & & & \\
\hline \multirow{2}{*}{3 . } & $\bar{x}$ & $642^{\mathrm{a}}$ & $621^{\mathrm{a}}$ & $614^{b}$ & $530^{c}$ & $642^{\mathrm{a}}$ & $638^{\mathrm{a}}$ & $623^{\mathrm{a}}$ & $554^{\mathrm{b}}$ & NS & ** & $\mathrm{NS}$ \\
\hline & $\mathrm{Sd}$ & 116,54 & 87,12 & 85,87 & 92,08 & 93,28 & 104,57 & 100,71 & 94,54 & & & \\
\hline
\end{tabular}

a-b Values within the row for each hybrid without same letter in superscript are statistically significantly different $(\mathrm{P}<0,05)$

* Statistically significant $(\mathrm{P}<0,05)$

** Statistically significant $(\mathrm{P}<0,01)$

NS no statistical significance

Obtained results, according to which reduction of protiens in feed resulted in decrease of boy weight in the first phase of fattening, in concordance with results of Reazeia et al.(2006) and Gomes et al.(2006). Also different response of hybrids 
during the investigation of the impact of nutrition program was alo reported by Mandrigal et al. (1994), Nikolova et al. (2007). However, in the paper by Saki et al. (2010) in the investigation of three programs of nutrition during starter period in two genotypes, no significant interactions between hybrids and nutrition programs were established.

In case of proveniences Cobb 500 and Ross 308, the lowest, insignificant difference in final body weight was registered by comparing T1 with T2 group, which consumed starter mixture during the period of two weeks. This result induces the question if chickens need starter mixtures longer than 14 days, during starter period. Obtained results are in accordance with research by Saleha et al. (1997) who evaluated the time proportion in nutrition using starter, grower and finisher mixtures in fattening chickens in fattening period of 42 days. This author indicated the significance of target body weight when planning the nutrition program in sense of duration of certain nutrition phases and provided recommendations for duration of use of certain mixtures depending on whether the chickens are fattened to $1 \mathrm{~kg}, 2 \mathrm{~kg}$ or $3 \mathrm{~kg}$ of final weight.

Obtained results can be associated with studies by Saleh et al.( 1996); Warren and Emmert (2000); Pope and Emert (2001) who pointed out the need for reevaluation of the traditional programs of nutrition and duration of each nutrition phase, based on their research of the effect of phase nutrition programs and different time proportions for starter, grower and finisher mixtures, and also taking into consideration the genetic improvements in broilers and reduced time for realization of body weight, as well as more expressed need for optimization of production from economical aspect.

Table 2 presents the data on feed conversion during the first fattening phase, for proveniences Cobb 500 and Ross 308.

During starter period (from 1 to 21 days), in chickens of both proveniences, by comparing values obtained for feed conversion, i.e. by comparing control T1 group to trial groups, it was observed that chickens of groups T3 and T4, with the greatest protein reduction, realized less favourable conversion. Also, in both hybrids, feed conversion values for $\mathrm{T} 1$ control group and $\mathrm{T} 2$ group with the mildest reduction of protein content were similar.

Table 2. Feed conversion in chickens according to fattening phases

\begin{tabular}{|c|c|c|c|c|c|c|c|c|}
\hline \multirow{3}{*}{$\begin{array}{c}\text { Period } \\
\text { (days) }\end{array}$} & \multicolumn{9}{|c|}{ Coed conversion } \\
\cline { 2 - 9 } & \multicolumn{9}{|c|}{ Cobb 500 } & Toss 308 & T3 & T4 \\
\hline $1-21$ & 1,643 & 1,658 & 1,897 & 2,233 & 1,648 & 1,659 & 1,888 & 1,942 \\
\hline
\end{tabular}

In the analysis of obtained data on feed conversion it was established that the most favourable feed conversion was in T1 group. Obtained results are in concordance with results obtained by Saki et al. (2010), in the research of different 
nutrition programs. However, in the paper by Saleha et al. (1997) in phase nutrition of broilers, no significant differences in feed conversion were detected between NCR program and two trial programs in which chickens consumed starter mixture to the age of 7 and 14 days.

Content of dry matter and nitrogen in faeces of Cobb 500 and Ross 308 chickens is presented according to nutrition treatments and weeks during the starter period, i.e. from week 1 to 3 (Table 3). Also, dynamics in changing of mixtures used in nutrition of studied genotypes depending on the nutrition program, is presented.

By analyzing data presented in Table 3, it can be observed that content of dry matter in chicken faeces varied depending on the feed consumed by chickens. In both investigated proveniences, dry matter content in faeces was mainly higher when grower mixture was consumed.

Nitrogen content in faeces, in chickens of Cobb 500 and Ross 308, was the highest in control $\mathrm{T} 1$ group which consumed during all three weeks mixtures containing $23 \%$ of crude proteins, i.e. group without protein reduction. Also, it can be observed that the drastic reduction of protein in mixture used in group T4 in both studied genotypes resulted in reduced nitrogen content in faeces, which is desirable from the ecological aspect. However, it should be pointed out that this program of nutrition had adverse effect on growth rate of chickens and feed conversion ratio, which makes it unacceptable from the aspect of production performances.

Table 3. Dry matter and nitrogen content in faeces

\begin{tabular}{|c|c|c|c|c|c|c|c|c|c|}
\hline \multirow{3}{*}{$\begin{array}{l}\frac{1}{0} \\
\frac{D}{3}\end{array}$} & \multirow{3}{*}{ Trait } & \multicolumn{8}{|c|}{ Dry matter and nitrogen content in faeces $(\%)$} \\
\hline & & \multicolumn{4}{|c|}{ Cobb 500} & \multicolumn{4}{|c|}{ Ross 308} \\
\hline & & $\begin{array}{c}\mathrm{T}_{1} \\
\text { starter }\end{array}$ & $\begin{array}{c}\mathrm{T}_{2} \\
\text { starter }\end{array}$ & $\begin{array}{c}\mathrm{T}_{3} \\
\text { starter }\end{array}$ & $\begin{array}{c}\mathrm{T}_{4} \\
\text { grower }\end{array}$ & $\begin{array}{c}\mathrm{T}_{1} \\
\text { starter }\end{array}$ & $\begin{array}{c}\mathrm{T}_{2} \\
\text { starter }\end{array}$ & $\begin{array}{c}\mathrm{T}_{3} \\
\text { starter }\end{array}$ & $\begin{array}{c}\mathrm{T}_{4} \\
\text { grower }\end{array}$ \\
\hline \multirow[t]{4}{*}{1.} & Dry mat. & 19,68 & 20,28 & 19,92 & 22,88 & 18,85 & 19,06 & 19,24 & 22,02 \\
\hline & Moisture & 80,32 & 79,72 & 80,08 & 77,12 & 81,15 & 80,94 & 80,76 & 77,98 \\
\hline & $\mathrm{N}$ in $\mathrm{DM}$ & 5,59 & 5,35 & 5,28 & 4,01 & 4,39 & 5,15 & 4,78 & 3,86 \\
\hline & & $\begin{array}{c}\mathrm{T}_{1} \\
\text { starter }\end{array}$ & $\begin{array}{c}\mathrm{T}_{2} \\
\text { starter }\end{array}$ & $\begin{array}{c}\mathrm{T}_{3} \\
\text { grower }\end{array}$ & $\begin{array}{c}\mathrm{T}_{4} \\
\text { grower }\end{array}$ & $\begin{array}{c}\mathrm{T}_{1} \\
\text { starter }\end{array}$ & $\begin{array}{c}\mathrm{T}_{2} \\
\text { starter }\end{array}$ & $\begin{array}{c}\mathrm{T}_{3} \\
\text { grower }\end{array}$ & $\begin{array}{c}\mathrm{T}_{4} \\
\text { grower }\end{array}$ \\
\hline \multirow[t]{4}{*}{2.} & Dry mat. & 18,68 & 19,95 & 20,53 & 19,78 & 16,67 & 18,26 & 20,09 & 19,46 \\
\hline & Moisture & 81,32 & 80,05 & 79,47 & 80,22 & 83,33 & 81,74 & 79,91 & 80,54 \\
\hline & $\mathrm{N}$ in $\mathrm{DM}$ & 5,01 & 4,98 & 4,02 & 3,88 & 4,94 & 5,10 & 4,18 & 3,98 \\
\hline & & $\begin{array}{c}\mathrm{T}_{1} \\
\text { starter }\end{array}$ & $\begin{array}{c}\mathrm{T}_{2} \\
\text { grower }\end{array}$ & $\begin{array}{c}\mathrm{T}_{3} \\
\text { grower }\end{array}$ & $\begin{array}{c}\mathrm{T}_{4} \\
\text { grower }\end{array}$ & $\begin{array}{c}\mathrm{T}_{1} \\
\text { starter }\end{array}$ & $\begin{array}{c}\mathrm{T}_{2} \\
\text { grower }\end{array}$ & $\begin{array}{c}\mathrm{T}_{3} \\
\text { grower }\end{array}$ & $\mathrm{T}_{4}$ \\
\hline \multirow[t]{3}{*}{3.} & Dry mat. & 18,24 & 21,83 & 19,98 & 21,19 & 17,62 & 21,86 & 20,90 & 21,68 \\
\hline & Moisture & 81,76 & 78,17 & 80,02 & 78,81 & 82,38 & 78,14 & 79,10 & 78,32 \\
\hline & $\mathrm{N}$ in $\mathrm{DM}$ & 5,23 & 4,50 & 4,25 & 4,67 & 5,05 & 4,38 & 4,10 & 4,56 \\
\hline
\end{tabular}

Similar results were obtained by Ferguson et al. (1997), in their study of the effect of nutrition with different content of crude proteins on growth, concentration 
of ammonia and manure composition. According to the results of said authors, drastic reduction of protein content during starter period increased significantly the need for feed, therefore it is not recommended, even though the reduction of protein induced reduced nitrogen emission.

Obtained results can be associated with the research in which the correlation between the protein content of mixtures used in broiler nutrition and nitrogen excretion was confirmed (Delezie et al., 2009; Namroud et al., 2008). Linear trend in increase of ammonia emission with the increase of crude protein content in diets was also established by Elwingwe and Svensson (1996). This indicates the need for further investigation of the nutrition program with comprehensive analyses in sense of economical and ecological aspects.

\section{Conclusion}

Phase nutrition included application of nutrition program with different frequency of changing starter, grower and finisher mixtures used in nutrition of Cobb 500 and Ross 308 chickens, with aim to determine the optimum for production in the economical and environmental sense.

Drastic reduction of proteins in T4 nutrition program resulted in significant decrease of body weight and unfavourable feed conversion in both studied hybrids. Chickens of Cobb 500 provenience were more sensitive to protein reduction. At the same time, drastic reduction of proteins in T4 nutrition program, in both studied genotypes, resulted in decrease of nitrogen content in faeces, which is desirable from ecological aspect. However, negative impact of this program on production performances makes it unacceptable. In proveniences Cobb 500 and Ross 308, the least, insignificant difference in body weight and similar feed conversion were established by comparing the control to T2 group, which consumed starter mixture for the period of two weeks, indicating the need for further research of this nutrition program.

Based on obtained results, it can be concluded that, composition and dynamics of changes of mixtures when formulating the program of phase nutrition must be taken into consideration in order to achieve both goals - decrease the protein content in feed, with diminished excretion of nitrogen in faeces and realizing good production results at the same time.

\section{Acknowledgment:}

Research was financed by the Ministry of Education, Science and Technological Development Republic of Serbia, project TR-31033. 


\title{
Uticaj fazne ishrane u starter periodu na proizvodne performanse i sadržaj azota u fecesu brojlera različitih genotipova
}

\author{
N. Tolimir, L. Perić, N. Milošević, M. Đukić -Stojčić, R. Jovanović, V. Bogdanović
}

\section{Rezime}

Cilj istraživanja je da se ispita uticaj fazne ishrane, odnosno različitih smeša za ishranu brojlera u kojima je sadržaj proteina smanjen fazno u starter periodu na proizvodne osobine tovnih pilića različitog genotipa i sadržaj azota u fecesu.

Razlika između grupa (tretmana) bila je u tipu smeša u starter periodu, a prema sledećem programu: T1 (kontrolna grupa) - ishrana smešom sa $23 \%$ proteina u trajanju od 1. do 21. dana; T2 - ishrana od 1. do 14. dana smešom sa $23 \%$ proteina i od 14 . do 21 . dana sa $20 \%$ proteina; T3 - ishrana od 1 . do 7 . dana smešom sa $23 \%$ proteina i od 7 . do 21 . dana sa $20 \%$ proteina; T4 - ishrana smešom sa $20 \%$ proteina u trajanju od 1. do 21. dana. U oglednom periodu (od 1. do 21. dana) praćeni su proizvodni parametri. Sadržaj azota u fecesu određen je na zbirnom uzorku.

Rezultati su pokazali da su pilići različitih genotipova ispoljili različitu osetljivost na restrikciju proteina. Poređenjem oglednih grupa sa kontrolnom u trećoj nedelji, kod pilića provenijence Ross 308 konstatovano je da je signifikantno manju telesnu masu ostvarila samo T4 grupa sa najstrožijom redukcijom proteina. Kod provenijence Cobb 500 signifikantno manja telesna masa utvrđena je za T3 i T4 oglednu grupu. Kod oba hibrida za T2 oglednu grupu utvrđena je nešto manja telesna masa, ali bez statistički značajne razlike u poređenju sa kontrolnom. Konverziju hrane kod oba genotipa imala je najveće vrednosti za T4 i T3 tretman. Programi fazne ishrane rezultirali su smanjenjem sadržaja azota $u$ fecesu.

$\mathrm{Na}$ osnovu dobijenih rezultata može se zaključiti da su primenjeni tretmani ishrane sa drastičnom restrikcijom proteina u starter periodu kod oba genotipa imali negativan uticaj na proizvodne performanse. Zbog toga se prilikom formulisanja programa fazne ishrane strogo mora voditi računa o sastavu i dinamici promene smeša, a kako bi se postigla oba cilja - smanjenje sadržaja proteina u hrani uz smanjenu ekskreciju azota i postizanje dobrih proizvodnih rezultata.

\section{References}

BAKER D.H., HAN Y. (1994): Ideal amino acid profile for chicks during the first three weeks post hatching. Poultry Science 73: 1441-1447. 
BELYAVIN C.G. (1999): Nutrition management of broiler programs. Animal Nutrition. Nottingham University Press, Nottingham, Recent Adv UK. Pages 93105

BREGENDAHL K, SELL J.L., ZIMMERMAN D.R. (2002): Effect of low-protein diets on growth performance and body composition of broiler chicks. Poultry Science 81: 1156-1167.

BUTERI C.B., TAVERNARI F. DE C., LELIS G.R, ROSTAGNO H.S., ALBINO L.F.T. (2009): Effects of different nutritional plans on broiler performance. Revista Brasileira de Ciencia Avicola 11 no 4.

DELLEZIE E., MAERTENS L., HUYGHEBAERT G., LIPPENS M. (2009): Can choice feeding improve performances and N-retention of broilers compared to a standard three-phase feeding schedule. British Poultry Science, Sep 50 (5): 573 582 .

ELWINGER K., SVENSSON L. (1996): Effect of dietary protein content litterand drinker type on ammonia emission from broiler houses. Journal of Agricultural Engineering Research 64: 197-208.

FERGUSON N.S., GATES R.S., TARABA J.L., CANTOR A.H, PESCATORE A.J., FORD M.J, BURNHAM D.J. (1997): The effect of dietary crude protein on growth, ammonia concentration, and litter composition in broilers. Poultry Science 77, 1481-1487.

FERGUSON N.S., GATES R.S., TARABA J.L., CANTOR A.H., PESCATORE A.J., STRAW M.L., FORD M.J., BURNHAM DJ. (1998): The effect of dietary protein and phosphorus on ammonia concentration and litter composition in broilers. Poultry Science, Vol. 77 (8): 1085-1093

GOMES G.A, ARAUJO L.F., PREZZI J.A., BARBOSA L.C.G.S., SAVIETTO D. AND FILHO CREN A.W. (2006): Period of feeding a pre starter diet on performance up to 42 days of broilers of different body weights at housing. book of Abstrats, XII European Poultry Conference, Italy, 298-299.

MADRIGAL S.A., WATKINS S.E., WALDROUP P.W. (1994): Feeding Programs Designed to Modify Early Growth Rates in Male Broilers Grown to 56 Days of Age. Journal of Applied Poultry Research 3:319-326.

NAMROUD N.F., SHIVAZAD M., ZAGHARI M. (2008): Effects of Fortifying Low Crude Protein Diet with Crystalline Amino Acids on Performance, Blood, Ammonia level, and Excreta Characteristics of Broiler chicks. Poultry Science 87: 2250-2258.

NIKOLOVA N., PAVLOVSKI Z., MILOŠEVIĆ N., PERIĆ L (2007): Uticaj različitog nivoa energije i proteina $u$ hrani na proizvodne parametre brojlerskih pilića dva genotipa. Biotechnology in Animal Husbandry, Vol. 23, br. 5-6-1, str. 551-557.

PETRIČEVIĆ V., PAVLOVSKI Z., ŠKRBIĆ Z., LUKIĆ M. (2011): The effect of genotype on production and slaughter properties of broiler chickens. Biotechnology in Animal Husbandry 2011 Volume 27, Issue 2, Pages: 171-181. 
POPE T., EMMERT J.L. (2001): Phase -feeding supports maximum growth performance of broiler chicks from forty -three to seventy-one days of age. Poultry Science 80 (3): 345-52.

PRAVILNIK O METODAMA UZIMANJA UZORAKA I METODAMA FIZIČKIH, HEMIJSKIH I MIKROBIOLOŠKIH ANALIZA STOČNE HRANE (1987): Službeni list SFRJ, broj 15/87.

REZAEI, A. TEIMOURI J. POURREZA, H. SAYYAHZADEH and P.W.WALDROUP (2006): Effect of diet dilution in the starter period on performance and carcass characteristics of broiler chicks. Journal Central European Agriculture, Volume 7, No. 1 (63-70).

SAKI A.A., MOMENI M., TABATABAEI M.M., AHMADI A., RAHMATI M.M.H., HEMATI MATIN H.R., JANJAN A. (2010): Effect of Feeding Programs on Broilers Cobb and Arbor Acres plus Performance. International Journal of Poultry Science 9 (8): 795-800,

SALEH E.A., WATKINS S.E., WALDROUP A.L., WALDROUP P.W. (2004): Effect of Dietary Nutrient Density on Performance and Carcass Quality of Male Broilers Grown for Further Processing. International Journal of Poultry Science 3 (1): 1-10.

SALEH E.A., WATKINS S.E., WALDROUP P.W. (1997): Changing Time of Feeding Starter, Grower and Finisher Diets for Broilers. 2. Birds grown to 2,2 kg. Journal of Applied Poultry Research 6: 6473.

SALEH, E.A., WARKINS S.E., AND WALDROUP AND W.P.(1996): Changing time of feeding starter, grower, and finisher diets for broilers.1. Birds grown to $1 \mathrm{~kg}$. J.Appl.Poult.Res. 5:269-275

TOLIMIR N, PERIĆ L, MILOŠEVIĆ N, BOGDANOVIĆ V (2010): The effect of multiphase nutrition on production performances of broilers. Biotechnology in animal husbandry, Vol.26, 1-2, 83-91.

WARREN W.A. AND EMMERT J.L (2000): Efficacy of phase-feeding in supporting growth performance of broiler chuck during the starter and finisher phases. Poult.Sci. 79:764-770. 